\title{
Effects of Varicocele on Serum Testosterone Levels and Changes of Testosterone Levels after Varicocelectomy among Infertile Men: A Prospective Controlled Study \\ Tamer Youssef Mohamed, Atef Mohamed Abdel Latif, Ahmed Mohamed AbdElmodaber, Mohamed Ali Kamar* \\ Endocrine Surgery Unit, Faculty of Medicine, Mansoura University, Egypt \\ * Corresponding author: Mohammed Ali Talaat Kamar, Mobile: (+20) 01096723523, E-mail: m.ali9020@ yahoo.com
}

\begin{abstract}
Background: Varicocele repair has been advocated as an option to prevent and treat low serum testosterone, even in men with normal semen quality. The association between clinical varicocele and impaired testosterone production is less clearly understood. Although, the conceptions of the negative impact of clinical varicocele on Leydig cell functions and the beneficial effect of varicocele repair on testosterone production have been proposed for decades.

Objective: To examine the hypotheses that clinical varicoceles affect baseline serum total testosterone levels and to study the effects of varicocelectomy on serum testosterone levels and semen quality in infertile men who suffer from varicocele.

Patients and Methods: This study included 100 patients (50 control and 50 cases) presented to the General Surgery and Endocrine Surgery Unit Outpatient Clinic at Mansoura University Hospitals with clinical varicocele for primary infertility. The study was conducted during the period between $1^{\text {st }}$ April 2020 and end of March 2021.

Results: Regarding preoperative and postoperative testosterone level among the intervention group, there were highly statistically significant increases in total testosterone as well as significant improvement in gonadal functions (significant increase in number of cases with euogonadism) after the operation among the intervention group (P < 0.001). however the percent of improvement was more than among hypogonadal compared to euogonadal.

Conclusion: Varicocelectomy was demonstrated to significantly improve both sperm quality (in terms of volume, count, motility and morphology) as well as serum testosterone in infertile men, especially in cases with hypogonadism. Keywords: Varicocele, Testosterone, Varicocelectomy, Semen analysis, Fertility.
\end{abstract}

\section{INTRODUCTION}

Varicocele is an abnormal dilatation of the pampiniform plexus of the veins that drain the testis. Restoration of this abnormality has been shown to cause positive effects on the spermatogenesis process (1). Clinical varicocele is a prevalent condition affecting $15 \%$ of general male population, $35 \%$ of patients with primary infertility, and $81 \%$ of men presenting for the management of secondary infertility. The associations between clinical varicocele, impaired spermatogenesis, and male infertility have long been recognized ${ }^{(2)}$.

Several studies documented improvements in semen parameters, hormonal profiles, and pregnancy rates after varicocele repair ${ }^{(3)}$.

On the other hand, the association between clinical varicocele and impaired testosterone production is less clearly understood. Although, the conceptions of the negative impact of clinical varicocele on Leydig cell functions and the beneficial effect of varicocele repair on testosterone production have been proposed for decades ${ }^{(4)}$.

Many studies have reported that varicocelectomy promotes Leydig cell function based on testosterone levels. In addition, research indicates that ageing in men can induce a reduction in serum testosterone levels ${ }^{(5)}$. High temperatures can reduce the activity of the 17-a hydroxyl progesterone aldolase enzyme, which results in decreased testosterone production. Thus, it is believed that treatment of varicocele may improve the function of Leydig cells, reactivate this enzyme, and increase testosterone production ${ }^{(6)}$.

In men with idiopathic varicocele, testicular biopsies demonstrated decreased tubular diameters, hyperplasia and atrophy of Leydig cells with cytoplasmic vacuolization, and decreased number of testosterone-positive Leydig cells ${ }^{(7)}$.

Although a considerable difference between serum testosterone levels among infertile and fertile varicocele men might be anticipated that varicoceles might impair Leydig cell functions and decrease serum testosterone levels among fertile men with varicocele as well ${ }^{(8)}$. Varicocele repair has been advocated as an option to prevent and treat low serum testosterone, even in men with normal semen quality ${ }^{(9)}$.

The aim of the present study was to examine the hypotheses that clinical varicoceles affect baseline serum total testosterone levels and to study the effects of varicocelectomy on serum testosterone levels and semen quality in infertile men who suffer from varicocele.

\section{PATIENTS AND METHODS}

This study included 100 patients (50 control and 50 cases) presented to the General Surgery and Endocrine Surgery Unit Outpatient Clinic, Mansoura University Hospitals with clinical varicocele for primary infertility. The study was conducted during the period between $1^{\text {st }}$ April 2020 and end of March 2021. All patients were radiologically evaluated using duplex 
scrotal ultrasound, semen analysis and serum total testosterone before surgery and 3-6 months postsurgery. The results of both were compared to the postoperative.

\section{Ethical approval:}

Approval of the Ethical Committee, Faculty of Medicine, Mansoura University was obtained. All patients signed an informed consent to their participation in this study.

\section{Inclusion Criteria:}

1. Varicocele group were men suffering from clinical varicocele with $>1$ year of primary infertility and impairment of at least one semen parameter.

2. Control group included healthy fertile men without varicoceles, whose baseline serum total testosterone levels were used for comparison with varicocele group.

3. Age $20-50$ years.

\section{Exclusion Criteria:}

1. Men with subclinical varicoceles.

2. Fertile men with clinical varicoceles presented with scrotal pain and/or swelling.

3 . Recurrent varicoceles.

4. Azoospermia.

5. Men receiving exogenous androgens.

6. History of testicular torsion, tumors and undescended testis.

7. Psychologically ill patient.

All patients were subjected to the following:

History: Complete history taking from all cases including:

Personal history: Name, age, occupation, residence, marital status, testicular trauma mumps Orchitis and special habits.

\section{Past history:}

- History of previous surgery.

- History of other comorbidities as diabetes mellitus, hypertension, cardiac, renal and hepatic diseases.

Drug history:

- History of receiving medications known to elicit imbalance androgen levels and the duration of taking it.

- History of drug allergy.

Family history: Family history of similar conditions.

General Examination: General appearance of the patient, conscious level, decubitus and vital signs (pulse, blood pressure and temperature). Examination of the head, chest, abdomen and extremities. Length, weight and BMI (Body Mass Index) of all patients were also recorded.

Local Examination: Assessment of characteristics of varicocele (right, left or both), grading, size of testis and any associated swelling. Through clinical examination all patients were examined in a warm room while both supine and standing (> $2 \mathrm{~min}$ ) and with no Valsalva maneuver.
Varicoceles were graded from I to III according to Dubin and Amelar varicocele grading system.

- Grade I: palpable only during Valsalva's maneuver.

- Grade II: palpable at rest but not visible.

- Grade III: palpable and visible at rest.

\section{Investigations:}

I. Routine full laboratory investigations:

- Random blood sugar, serum creatinine, liver function tests, complete blood count, INR, and blood grouping.

\section{Special lab investigations:}

- Semen analysis: were obtained from infertile men by masturbation after 3-5 days of sexual abstinence. Semen analysis was done before surgery and repeated (3-6 months) after varicocelectomy to evaluate the effects of varicocele repair upon the quality of the semen parameters. Semen parameters (concentration, motility, and morphology) were assessed according to WHO guidelines. All varicocele men had semen analyses before surgery that showed at least one abnormal parameter (count $<15$ million/ml, motility $<40 \%$ and morphology $<4 \%$ normal forms).

- Serum total testosterone levels assay: Blood samples from varicocele group and control group were withdrawn and base line serum total testosterone levels were compared between both groups prior to surgery. Blood samples were collected in the morning between 8:00 AM and 11 AM. Serum total testosterone measurements were repeated at (3-6 months) after surgery for varicocele group in order to reassess the changes in serum testosterone levels.

\section{Duplex scrotal ultra sound:}

Clinical findings were confirmed by duplex scrotal US. Duplex examination for all patients was done at Mansoura University Radiology Unit. Every patient was examined preoperatively to confirm the clinical diagnosis of varicocele and to diagnose a possible contralateral subclinical varicocele. Before Duplex examination, the patient was asked to shave well the scrotum and lower abdomen on both sides. A pencilprobe Duplex $(9 \mathrm{MHz})$ stethoscope was used. The patient was examined in the upright position and the conducting gel was applied to the upper aspect of the scrotum. There was complete acoustical silence. The patient was examined during quiet respiration and during Valsalva's maneuver. In varicocele patient, there was a characteristic audible venous rush (reflux) indicative of retrograde filling of the varicocele. In varicocele patient during quiet respiration there was continuous venous regurge (grade III), intermittent venous regurge (grade II) or no spontaneous venous regurge (grade I). During Valsalva's maneuver, varicocele patient showed maintained venous regurge. 


\section{Post-operative follow up:}

Early follow up: Early Post-operative follow up was performed during the $1^{\text {st }}$ week for (pain, fever, scrotal edema, wound infection, and removal of stitches).

Late follow up: Clinical assessment of the patients through $3^{\text {rd }}$ and $6^{\text {th }}$ months was done to detect any postoperative complication including hydrocele, recurrence and testicular atrophy. Serum total testosterone level and semen analysis were repeated at $3^{\text {rd }}$ and $6^{\text {th }}$ months postoperatively and compared to the preoperative one.

\section{Statistical analysis}

Data were fed to the computer and analyzed using IBM SPSS Corp. (IBM SPSS Statistics for Windows, Version 22.0. Armonk, NY: IBM Corp.). Qualitative data were described using number and percent. Quantitative data were described using median (minimum and maximum) for non-parametric data and mean \pm standard deviation for parametric data after testing normality using Shapiro-Wilk test. Significance of the obtained results was judged at the (0.05) level.

\section{RESULTS}

This prospective, non-randomized controlled study was conducted on 100 adult men aged between 20 and 50 years old. They were chosen according to the inclusion and exclusion criteria.

Table (1) illustrated the age and duration of infertility of the studied groups. The mean age of the studied groups were $31.52 \pm 6.25$ and $31.02 \pm 5.84$ years for the control arm and the intervention arm respectively with no significant differences $(\mathrm{P}>0.05)$. The mean infertility duration of the intervention arm was $27.24 \pm 8.83$ months.

Table (1): Age and Duration of infertility of the studied groups

\begin{tabular}{|l|c|c|c|}
\hline & $\begin{array}{c}\text { Control } \\
\mathbf{a r m} \\
\mathbf{n}=\mathbf{5 0}\end{array}$ & $\begin{array}{c}\text { Intervention } \\
\mathbf{a r m} \\
\mathbf{n = 5 0}\end{array}$ & $\begin{array}{c}\text { Test of } \\
\text { significance }\end{array}$ \\
\hline $\begin{array}{l}\text { Age/years } \\
\text { Mean } \pm \text { SD }\end{array}$ & $\begin{array}{c}31.52 \pm \\
6.25\end{array}$ & $31.02 \pm 5.84$ & $\mathrm{t}=0.413$ \\
$\mathrm{p}=0.680$
\end{tabular}

t:Student $\mathrm{t}$ test p:probability NA: Not applicable
Table (2) illustrated the duplex scrotal grading among intervention arm. Regarding Duplex scrotal left side, most of cases $(62 \%)$ were G III with only $38 \%$ of which were GII. Regarding Duplex scrotal right side most of cases $(52 \%)$ were G II followed by G I (30\%) then GIII (18\%).

Table (2): Duplex scrotal grading among intervention arm

\begin{tabular}{|l|c|c|}
\hline & \multicolumn{2}{|c|}{ Intervention arm } \\
\hline & $\mathbf{N = 5 0}$ & \% \\
\hline $\begin{array}{l}\text { Duplex scrotal left } \\
\text { side }\end{array}$ & & \\
GII & 19 & 38.0 \\
GIII & 31 & 62.0 \\
\hline Duplex scrotal right & & \\
side & 15 & 30.0 \\
G I & 26 & 52.0 \\
GII & 9 & 18.0 \\
GIII & & \\
\hline
\end{tabular}

Table (3) displayed that pre-operative total testosterone level demonstrated highly statistically significant increase in the controls compared to the intervention group $(\mathrm{P}<0.001)$.

Table (3): Comparison of total testosterone between control and intervention groups

\begin{tabular}{|c|c|c|c|}
\hline $\begin{array}{c}\text { Total } \\
\text { testosteron } \\
\mathrm{e} \\
(\mathrm{ng} / \mathrm{ml})\end{array}$ & $\begin{array}{c}\text { Contro } \\
1\end{array}$ & $\begin{array}{c}\text { Interventio } \\
\text { n arm }\end{array}$ & $\begin{array}{c}\text { Test of } \\
\text { significanc } \\
\text { e }\end{array}$ \\
\hline $\begin{array}{l}\text { Pre- } \\
\text { operative } \\
\text { median } \\
\text { (range) }\end{array}$ & $\begin{array}{c}5.29 \\
(3.56- \\
6.75)\end{array}$ & $\begin{array}{c}3.73 \\
(2.11-6.8)\end{array}$ & $\begin{array}{c}\mathrm{z}=6.47 \\
\mathrm{p}<0.001 *\end{array}$ \\
\hline
\end{tabular}

Table (4) demonstrated testosterone level change pre- and post-operative among intervention group. There were highly statistically significant increases in total testosterone as well as significant improvement in gonadal functions (significant increase in number of cases with euogonadism) after the operation among the intervention group $(\mathrm{P}<0.001)$. However, the percent of improvement was more than among hypogonadal compared to euogonadal. 
Table (4): Testosterone level change pre and post-operative among intervention group

\begin{tabular}{|l|c|c|c|c|c|}
\hline & $\begin{array}{c}\text { Pre- } \\
\text { operative }\end{array}$ & $\begin{array}{c}\text { Post-operative } \\
\mathbf{3} \text { months }\end{array}$ & $\begin{array}{c}\text { Post-operative } \\
\text { 6 months }\end{array}$ & $\begin{array}{c}\text { Test of } \\
\text { significance }\end{array}$ & $\begin{array}{c}\text { Percent of } \\
\text { improvement }\end{array}$ \\
\hline $\begin{array}{l}\text { Total testosterone } \\
\text { (ng/ml) }\end{array}$ & $\begin{array}{c}3.73 \\
(2.11-6.8)\end{array}$ & $\begin{array}{c}3.99 \\
(2.36-5.76)\end{array}$ & $\begin{array}{c}4.05 \\
(2.36-5.67)\end{array}$ & $\begin{array}{c}\mathrm{P} 1<0.001^{*} \\
\mathrm{P} 2<0.001^{*} \\
\mathrm{P} 3=0.06\end{array}$ & $\begin{array}{c}\% 1=7.9 \\
\% 2=9.3 \\
\% 3=1.2\end{array}$ \\
\hline $\begin{array}{l}\text { Hypogonadism (<2.62) } \\
\text { euogonadism (2.62- } \\
\text { 8.53) }\end{array}$ & $23(46.0)$ & $6(12.0)$ & $5(10.0)$ & $\begin{array}{c}\mathrm{P} 1<0.001^{*} \\
\mathrm{P} 2<0.01^{*}\end{array}$ & \\
\hline Hypogonadal & $27(54.0)$ & $44(88.0)$ & $45(90.0)$ & $\mathrm{P} 3=1.0$ & \\
& 2.37 & $2.44(2.36-$ & $2.43(2.36-2.6)$ & $\mathrm{P} 1<0.001^{*}$ & $\% 1=13.5$ \\
& $(2.11-2.6)$ & $2.53)$ & & $\mathrm{P} 2<0.001^{*}$ & $\% 2=13.8$ \\
& & & & $\mathrm{P} 3=0.18$ & $\% 3=1.0$ \\
\hline Euogonadal & 4.16 & 4.05 & 4.05 & $\mathrm{P} 1<0.001^{*}$ & $\% 1=10.5$ \\
& $(3.56-6.8)$ & $(2.86-5.76)$ & $(2.67-5.67)$ & $\mathrm{P} 2<0.001^{*}$ & $\begin{array}{c}\% 2=12.2 \\
\% 3=0.2\end{array}$ \\
\hline
\end{tabular}

Table (5) showed sperm count change pre- and post-operative among intervention group. There was highly statistically significant increase in sperm count following the operation (at 3 and 6 months) (P < 0.001). In addition, there was statistically significant increase in sperm count 3 months and 6 months postoperative $(\mathrm{P}<0.001)$. However, there was no significant increase in count among 3 months postoperative and 6 months postoperative $(\mathrm{P}>0.05)$.

Table (5): Sperm count change pre- and post-operative among intervention group:

\begin{tabular}{|l|c|c|c|c|c|}
\hline Semen analysis. & $\begin{array}{c}\text { Pre- } \\
\text { operative }\end{array}$ & $\begin{array}{c}\text { Post- } \\
\text { operative 3 } \\
\text { months }\end{array}$ & $\begin{array}{c}\text { Post- } \\
\text { operative 6 } \\
\text { months }\end{array}$ & $\begin{array}{c}\text { test of } \\
\text { significance }\end{array}$ & $\begin{array}{c}\text { percent of } \\
\text { improvement }\end{array}$ \\
\hline Count & 11.97 & 25.64 & 27.49 & $\mathrm{P} 1<0.001^{*}$ & $\% 1=33.9$ \\
Million/ml) & $(0.6-95.94)$ & $(14.5-86.57)$ & $(18.55-76.53)$ & $\mathrm{P} 2<0.001^{*}$ & $\% 2=36.8$ \\
\hline$<15$ Million & $30(60.0)$ & $1(2.0)$ & $1(2.0)$ & $\mathrm{P} 3=0.054$ & $\% 3=2.2$ \\
\hline 15 Million & $20(40.0)$ & $49(98.0)$ & $49(98.0)$ & $\mathrm{P} 2<0.001^{*}$ & \\
& & & & $\mathrm{P} 3=1.0$ & \\
\hline
\end{tabular}

Table (6) demonstrated sperm motility change pre- and post-operative among intervention group. There were highly statistically significant improvements in sperm motility following the operation (at 3 and 6 months postoperative) (P $<0.001)$.

Table (6): Sperm motility change pre- and post-operative among intervention group

\begin{tabular}{|l|c|c|c|c|c|}
\hline $\begin{array}{c}\text { Semen } \\
\text { analysis }\end{array}$ & Pre-operative & $\begin{array}{c}\text { Post- } \\
\text { operative 3 } \\
\text { months }\end{array}$ & $\begin{array}{c}\text { Post- } \\
\text { operative 6 } \\
\text { months }\end{array}$ & $\begin{array}{c}\text { Test of } \\
\text { significance }\end{array}$ & $\begin{array}{c}\text { Percent of } \\
\text { improvement }\end{array}$ \\
\hline Motility & 29.55 & 36.07 & 38.19 & $\mathrm{P} 1<0.001^{*}$ & $\% 1=26.4$ \\
& $(6.28-38.5)$ & $(21.5-43.68)$ & $(25.8-43.6)$ & $\mathrm{P} 2<0.001^{*}$ & $\% 2=36.02$ \\
& & & & $\mathrm{P} 3<0.001^{*}$ & $\% 3=7.6$ \\
\hline $\mathbf{4 4 0 \%}$ & $50(100)$ & $43(86.0)$ & $35(70.0)$ & $\mathrm{p} 1=0.008^{*}$ & \\
$\mathbf{4 4 0 \%}$ & $0(0)$ & $7(14.0)$ & $15(30.0)$ & $\mathrm{p} 2<0.001^{*}$ & \\
& & & & $\mathrm{p} 3=0.005^{*}$ & \\
\hline
\end{tabular}

Table (7) demonstrated sperm morphology change pre- and post-operative among intervention group. There were highly statistically significant improvements in sperm morphology following the operation (at 3 and 6 months) (P $<0.001)$. However, there was no significant improvement in morphology among 3 months postoperative and 6 months postoperative $(\mathrm{P}>0.05)$.

Table (7): Sperm morphology change pre and post-operative among intervention group: 


\begin{tabular}{|l|c|c|c|c|c|}
\hline $\begin{array}{c}\text { Semen } \\
\text { Analysis }\end{array}$ & $\begin{array}{c}\text { Pre- } \\
\text { operative }\end{array}$ & $\begin{array}{c}\text { Post- } \\
\text { operative 3 } \\
\text { months }\end{array}$ & $\begin{array}{c}\text { Post- } \\
\text { operative 6 } \\
\text { months }\end{array}$ & $\begin{array}{c}\text { Test of } \\
\text { significance }\end{array}$ & $\begin{array}{c}\text { Percent of } \\
\text { improvement }\end{array}$ \\
\hline Morphology & $20(0-89)$ & $27(11-77)$ & $28.4(13-76)$ & $\mathrm{P} 1<0.001^{*}$ & $\% 1=19.84$ \\
& & & & $\mathrm{P} 2<0.001^{*}$ & $\% 2=23.8$ \\
$\mathrm{P} 3=0.06$ & $\% 3=1.6$ \\
\hline$<4 \%$ & $6(12.0)$ & 0 & 0 & $\mathrm{P} 1<0.001^{*}$ & \\
$\geq 4 \%$ & $44(88.0)$ & $50(100)$ & $50(100 \%)$ & $\mathrm{P} 2<0.001^{*}$ & \\
& & & & $\mathrm{P} 3=1.0$ & \\
\hline
\end{tabular}

\section{DISCUSSION}

This prospective, non-randomized controlled study was conducted on 50 infertile men with clinical varicocele and 50 fertile men as control group at Endocrine Surgery Unite and General Surgery Department (6), Mansoura University Hospitals. Both groups didn't take medications known to elicit imbalance of androgen levels.

Testosterone level as well as semen parameters including volume, motility, and morphology were assessed before and after surgery and compared to the control group (fertile men).

In terms of the demographic characters, the mean ages were $31.52 \pm 6.25$ and $31.02 \pm 5.84$ for the control arm and the intervention arm respectively with no significant differences $(\mathrm{P}>0.05)$. Additionally, the medical and surgical history demonstrated insignificant differences among both groups $(\mathrm{P}>0.05)$. Such finding demonstrated that, both groups were comparable prior to surgery in terms of the demographic characters as well as past medical and surgical conditions. Thus, such parameters were not interfering with the net results of the study and varicocelectomy was the only interfering factor. Similarly, Jangkhah et al. ${ }^{\left({ }^{10)}\right.}$ demonstrated that, the mean ages of infertile was $32.2 \pm 5.23$ years and for fertile men was $32.8 \pm 5.27$ years that was not significantly different $(\mathrm{P}=0.328)$.

The current study reported that, regarding Duplex scrotal left side, most of cases (62\%) were G III with only $38 \%$ of which were GII. Regarding Duplex scrotal right side, most of cases $(52 \%)$ were G II followed by G I (30\%), then GIII (18\%). Similarly, Shabana et al. (11) reported in their study that, varicocele grade I was diagnosed in 42 (34.1\%) patients, while the other $81(65.9 \%)$ patients had grade II or III.

Concerning preoperative testosterone level, the current study displayed that, the controls (fertile men) were associated with a significant increase in testosterone level compared to the intervention group $(\mathrm{P}$ $<0.001)$. Therefore, varicoceles might cause androgen deficiency, and treatment of varicoceles might increase testosterone levels in hypogonadal men ${ }^{(12)}$. The actual explanation could be due to the fact that varicocele might cause deterioration in Leydig cell functions, and it is a significant risk factor for hypogonadism. Some controversial issues have been raised in the treatment of hypogonadal men with varicoceles. Symptomatic hypogonadal men with varicoceles have two options: testosterone replacement therapy or varicocele treatment. Both approaches have some advantages and disadvantages (12). This comes in accordance with Zohdy et al. ${ }^{(13)}$ who displayed that, patients who underwent varicocelectomy demonstrated a significant postoperative improvement in serum testosterone levels $(379.1 \pm 205.8$ to $450.1 \pm 170.2 \mathrm{ng} / \mathrm{dL})(\mathrm{P}<0.0001)$.

Considering that varicocele has been universally accepted to negatively impact testis function, including paracrine and endocrine functions of the Leydig cells, the relationship between varicocele and diminished androgen levels appears to be reversed with varicocele repair. However, further studies are needed to better understand the multifactorial pathophysiology of varicocele-mediated Leydig cell dysfunction (14). In the same line, Hsiao et al. (4) conducted their study on a total of 59 patients who had undergone bilateral varicocelectomy and 19 unilateral varicocelectomy. Overall, an increase in testosterone was seen in 65 of the 78 men (83\%). They showed that testosterone levels lower than $400 \mathrm{ng} / \mathrm{dl}$ improved considerably in individuals after varicocele treatment. The mean serum testosterone level increased from 308.4 to $417.5 \mathrm{ng} / \mathrm{dL}$, with a mean increase of $109.1 \pm$ $12.8 \mathrm{ng} / \mathrm{dL}(\mathrm{n}=78)$. The improvements in serum testosterone levels were seen regardless of the clinical grade. Additionally, Srini and Veerachari ${ }^{(\mathbf{9})}$ reported that, the mean total testosterone level increased significantly after varicocelectomy (1.644 \pm 0.029 to $2.461 \pm 0.0198 \mathrm{ng} / \mathrm{dL})(\mathrm{P}<0.0001)$ and testicular size correlated with the mean change in total testosterone $(\mathrm{P}=0.001)$. However, the magnitude of this increase wasn't the same in all participants. These findings suggested that improved spermatogenesis might have a mechanism other than increased testosterone production. Moreover, classification of men based on their preoperative total testosterone may explain variation in total testosterone improvement between different studies ${ }^{(9)}$.

While Jangkhah et al. ${ }^{(\mathbf{1 0})}$ are in disagreement as they reported that fertile men had higher mean testosterone levels $(583 \pm 263 \mathrm{ng} / \mathrm{dl})$ compared to infertile men $(567 \pm 222 \mathrm{ng} / \mathrm{dl})$ before the operation, however this was not statistically significant difference $(\mathrm{P}=0.558)$. The reasonable explanation of such 
discrepancies between the current study and Jangkhah et al. ${ }^{(10)}$ research could be referred to other parameters that supposedly affect total testosterone levels. These parameters included age, grade, and testis size. Thus, Jangkhah et al. ${ }^{(\mathbf{1 0})}$ determined that the difference in the sizes of the left and right testes impacted total testosterone level in infertile men. Additionally, Pasqualotto et al. ${ }^{(15)}$ reported that postoperative serum TT increases were limited to patients who had more than 10 veins ligated during varicocelectomy. The clinical grade and the vein diameter might not be the determining factors for how varicocele affects testicular functions. Also, Shiraishi et al. ${ }^{(16)}$ showed that scrotal temperature is related to the deterioration in sperm density, sperm motility, and serum FSH and testosterone levels irrespective of the varicocele grade.

An important note has to be considered, although varicocelectomy might halt the accelerated decline in testosterone levels, the repair might only offer a transient increase. Eventually, men might return to the normal rate of testosterone decline seen in those without varicoceles. Thus, although men can be counseled that varicocelectomy might initially improve their testosterone levels and slow the rate of decline, they might still require testosterone supplementation or other medical treatment of their low testosterone level. This would depend on the patient's symptoms, serum testosterone levels, age, and other comorbidities shown to be associated with testosterone deficiency syndrome (4).

Regarding preoperative and postoperative testosterone level among the intervention group, there were highly statistically significant increases in total testosterone as well as significant improvement in gonadal functions (significant increase in number of cases with euogonadism) after the operation among the intervention group $(\mathrm{P}<0.001)$. However the percent of improvement was more than among hypogonadal compared to euogonadal. In harmony with the current study, Zohdy et al. ${ }^{(13)}$ revealed that, there was a significant improvement in gonadal functions (significant increase in number of cases with euogonadism) after the operation. Out of the 49 patients in intervention group with hypogonadism at baseline assessment (total testosterone $<300 \mathrm{ng} / \mathrm{dL}$ ), 37 (75.5\%) exhibited a postoperative normalization of total testosterone. Additionally, Srini and Veerachari (9) reported that, the total testosterone normalized in $77 \%$ of the varicocelectomy patients with hypogonadism. On the contrary, Jangkhah et al. (10) conducted a prospective study on 115 subjects with clinical varicocele grades II and III and 240 fertile men as the control group. Total volume of testosterone serum level (ng/dl) and semen quality were compared before and after microscopic varicocelectomy. They demonstrated that, there were similar mean values for adjusted testosterone levels between the varicocele $(567 \pm 222$ $\mathrm{ng} / \mathrm{ml})$ and control (583 $\pm 263 \mathrm{ng} / \mathrm{ml})$ groups. Varicocelectomy resulted in an insignificant rise in testosterone levels from $567 \pm 222 \mathrm{ng} / \mathrm{dl}$ to $594 \pm 243$ $\mathrm{ng} / \mathrm{dl}(\mathrm{P}=0.27)$.

Regarding sperm volume, the current study illustrated that, there was highly statistically significant increase in semen volume following the operation (at 3 and 6 months) ( $\mathrm{P}<0.001)$. However, there was no significant increase in volume among 3 months postoperative and 6 months postoperative $(\mathrm{P}>0.05)$. There is no literature regarding defined cut-off values for parameters that can predict a successful outcome of varicocelectomy on semen analysis (17). In disagreement, Srini and Veerachari ${ }^{(9)}$ reported that, there was no significant change in sperm volume as well as viability of sperm after surgery. Moreover, Jangkhah et al. (10) demonstrated that, there was insignificant increase in semen volume following surgery $(\mathrm{P}>0.05)$.

In terms of sperm count change pre- and postoperative among intervention group, the current study displayed that there was highly statistically significant increase in sperm count following the operation (at 3 and 6 months) ( $\mathrm{P}<0.001)$. However, there was no significant increase in count among 3 months postoperative and 6 months postoperative $(\mathrm{P}>0.05)$. In accordance, Jangkhah et al. (10) demonstrated that, among semen parameters only mean sperm concentration significantly increased after varicocelectomy in comparison with the controls. In the same line, Srini and Veerachari ${ }^{(9)}$ reported that, there was significant improvement in sperm count from 12.18 \pm 5.53 million $/ \mathrm{mL}$ to $17.43 \pm 6.17$ million $/ \mathrm{mL}(\mathrm{P}<$ 0.001 ) after surgery. Moreover, Hsiao et al. ${ }^{(4)}$ found that microsurgical varicocelectomy resulted in substantial changes in sperm count and concentration in all age groups especially in men aged between 40 and 60 years. Also, Choi et al. ${ }^{(18)}$ demonstrated that, sperm concentration significantly increased after microsurgical subinguinal varicocelectomy.

In terms of sperm motility, the current study displayed that, there were highly statistically significant improvements in sperm motility following the operation (at 3 and 6 months) ( $\mathrm{P}<0.001)$. Also, there was highly statistically significant improvement in motility among 3 months postoperative and 6 months postoperative $(\mathrm{P}<0.001)$. In accordance, Srini and Veerachari ${ }^{(9)}$ reported that, there was significant improvement in sperm motility $(\mathrm{P}<0.001)$ after surgery. Also, Choi et al. ${ }^{(\mathbf{1 8})}$ demonstrated that, sperm motility significantly improved after microsurgical subinguinal varicocelectomy. Meanwhile, for normalization of sperm motility, significant correlations were found with age and preoperative sperm motility. In the same line, Krishna et al. ${ }^{(19)}$ reported that, varicocelectomy significantly improved sperm motility. There were 32 to $41 \%$ of infertile 
patients who achieved pregnancy spontaneously. On the contrary, Jangkhah et al. ${ }^{(10)}$ demonstrated that, there was insignificant increase in sperm motility following surgery.

With regard to sperm morphology, the current study displayed that, there were highly statistically significant improvements in sperm morphology following the operation (at 3 and 6 months) $(\mathrm{P}<0.001$ ). However, there was no significant improvement in morphology among 3 months postoperative and 6 months postoperative $(\mathrm{P}>0.05)$. Also, Choi et al. ${ }^{(18)}$ demonstrated that, sperm morphology significantly improved after microsurgical subinguinal varicocelectomy. In disagreement, Srini and Veerachari ${ }^{(9)}$ reported that, there was no significant change in percent of abnormally formed sperm after surgery.

The discrepancies among results (in terms of semen quality) could be referred to several reasons, for example, either the cases performed unilateral or bilateral varicocelectomy as Zohdy et al. ${ }^{(13)}$ who demonstrated that, the mean change in total testosterone in men who underwent the bilateral varicocelectomy was higher than for those who underwent left varicocelectomy ( $85.8-110.1$ vs. 64.1 _ $96.8 \mathrm{ng} / \mathrm{dL})$. Additional reasons may be due to the alterations of sample sizes and difference in exclusion criteria among researches. Also, alterations between right testis size, which was demonstrated to be correlated with total testosterone level as reported by Jangkhah et al. ${ }^{(10)}$. Another main important reason may be due to associated risk factors such as obesity (alteration body mass index (BMI) among subjects), associated comorbidities as Jangkhah $\boldsymbol{e t}$ al. ${ }^{(\mathbf{1 0})}$ didn't give any data about the past medical history of their cases, which was demonstrated to be an important precipitating factors responsible to such alterations.

With regards to the correlation between duplex scrotal and both testosterone and semen analysis results among studied intervention group, the current study demonstrated that, there were no statistically significant correlations among duplex scrotal and both preoperative and post-operative ( 3 months and 6 months) total testosterone and semen analysis (in terms of volume, count, motility and morphology) $(\mathrm{P}>0.05)$. In accordance, Zohdy et al. ${ }^{(\mathbf{1 3})}$ demonstrated that, neither operating vein diameter $3.6 \pm 0.57 \mathrm{~mm}$ nor testicular size $10.46 \pm 3.3 \mathrm{~mL}$ correlated with the mean change in total testosterone $(71.1 \pm 101.2$ $\mathrm{ng} / \mathrm{dL})(\mathrm{r}=0.162, \mathrm{P}=0.183$ and $\mathrm{r}=-0.077, \mathrm{P}=0.536$, respectively). In the same line, Hsiao et al. ${ }^{(4)}$ found that $83 \%$ of the patients exhibited an increase in postoperative testosterone, and varicocele repair provided increased level of serum testosterone, regardless of the varicocele grading. Thus, they concluded that, no statistically significant correlations among varicocele grade and testosterone level following the operation. Moreover, Tanrikut et al. ${ }^{(1)}$ reported that, there was no association between change in testosterone level and age, laterality of varicocele, or varicocele grade. Additionally, Baazeem et al. ${ }^{\left({ }^{(20)}\right.}$ noted an increase of total motile sperm count by more than $50 \%$ and spontaneous pregnancy rate of $37 \%$ achieved after varicocelectomy. While, Jangkhah et al. (10) reported that, Pearson correlation showed a significant correlation between total testosterone and right testis size $(\mathrm{r}=0.21, \mathrm{P}=0.026)$ in infertile men with varicocele before surgery.

\section{CONCLUSION}

Varicocelectomy was demonstrated to significantly improve both sperm quality (in terms of motility, volume and morphology) as well as serum testosterone in infertile men, especially in cases with hypogonadism.

\section{REFERENCES}

1. Tanrikut C, Goldstein M, Rosoff S et al. (2011): Varicocele as a risk factor for androgen deficiency and effect of repair. BJU International, 108 (9): 1480-1484.

2. Alsaikhan B, Alrabeeah K, Delouya G et al. (2016): Epidemiology of varicocele. Asian Journal of Andrology, 18 (2): 179-185.

3. Tavalaee M, Bahreinian M, Barekat F et al. (2015): Effect of varicocelectomy on sperm functional characteristics and DNA methylation. Andrologia, 47 (8): 904-909.

4. Hsiao W, Rosoff J, Greenwood E et al. (2013): Varicocelectomy is associated with increases in serum testosterone independent of clinical grade. Urology, 81 (6): 1213-1218.

5. Damsgaard J, Joensen U, Carlsen E et al. (2016): Varicocele is associated with impaired semen quality and reproductive hormone levels: a study of 7035 healthy young men from six European countries. European Urology, 70 (6): 1019-1029.

6. Christe N, Meier C (2015): Hypotestosteronaemia in the aging male: should we treat it? Swiss Medical Weekly, 145: 4748.

7. Li F, Yue H, Ando M et al. (2012): Effect of surgical repair on testosterone production in infertile men with varicocele: A meta-analysis. International Journal of Urology, 19 (2): 149-154.

8. Fisch H, Hyun G (2012): Varicocele repair for low testosterone. Current Opinion in Urology, 22 (6): 495498.

9. Srini V, Veerachari S (2011): Does varicocelectomy improve gonadal function in men with hypogonadism and infertility? Analysis of a prospective study. International Journal of Endocrinology, 1: 916380.

10. Jangkhah M, Farrahi F, Gilani M et al. (2018): Effects of varicocelectomy on serum testosterone levels among infertile men with varicocele. International Journal of Fertility \& Sterility, 12 (2): 169-172.

11. Shabana W, Teleb M, Dawod T et al. (2015): Predictors of improvement in semen parameters after 
varicocelectomy for male subfertility: A prospective study. Canadian Urological Association Journal, 9 (910): 579-82.

12. Çayan S, Akbay E, Saylam B et al. (2020): Effect of varicocele and its treatment on testosterone in hypogonadal men with varicocele: review of the literature. Balkan Medical Journal, 37 (3): 121-25.

13. Zohdy W, Ghazi S, Arafa M (2011): Impact of varicocelectomy on gonadal and erectile functions in men with hypogonadism and infertility. The Journal of Sexual Medicine, 8 (3): 885-893.

14. Hayden R, Tanrikut C (2016): Testosterone and varicocele. Urologic Clinics, 43 (2): 223-232.

15. Pasqualotto $F$, Lucon $A$, de Góes $P$ et al. (2005): Relationship between the number of veins ligated in a varicocelectomy with testicular volume, hormonal levels and semen parameters outcome. Journal of Assisted Reproduction and Genetics, 22 (6): 245-249.

16. Shiraishi K, Takihara H, Matsuyama H (2010): Elevated scrotal temperature, but not varicocele grade, reflects testicular oxidative stress-mediated apoptosis. World Journal of Urology, 28 (3): 359-364.

17. Abdel-Meguid T, Farsi H, Al-Sayyad A et al. (2014): Effects of varicocele on serum testosterone and changes of testosterone after varicocelectomy: a prospective controlled study. Urology, 84 (5): 1081-1087.

18. Choi W, Kim T, Paick J et al. (2009): Factors related to improvement or normalization of semen parameters after microsurgical subinguinal varicocelectomy. Korean Journal of Urology, 50 (1): 39-45.

19. Krishna S, Shaik A, Sailaja S et al. (2015): Outcome of varicocelectomy with different degrees of clinical varicocele in infertile male. Advances in Andrology, 2015: 1-9.

20. Baazeem A, Belzile E, Ciampi A et al. (2011): Varicocele and male factor infertility treatment: a new meta-analysis and review of the role of varicocele repair. European Urology, 60 (4): 796-808. 